\title{
Responses of Stock Price to the Public Announcement of Forms of Borrowing
}

\author{
Khairul Kabir Sumon ${ }^{1} \&$ Md. Sazib Miyan ${ }^{1}$ \\ ${ }^{1}$ Department of Finance and Banking, Begum Rokeya University, Rangpur, Bangladesh \\ Correspondence: Khairul Kabir Sumon, Department of Finance and Banking, Begum Rokeya University, \\ Rangpur, Bangladesh. Tel: 880-173-433-5817. E-mail: kksumon@brur.ac.bd
}

Received: August 11, 2021

Accepted: September 16, 2021

Online Published: September 25, 2021

doi:10.5539/ijef.v13n10p169

URL: https://doi.org/10.5539/ijef.v13n10p169

\begin{abstract}
This study investigates the question of whether an announcement of bank loan agreement increases the abnormal return. That is, the bank loan agreement conveys some positive information about the borrowing firm. The study used three different event windows (i.e.) two-day, three-day, and five-day windows to check the effect of the announcement for a period of 1995 to 2015. In order to measure the effect, the return has been calculated using the market model, then CARs have been calculated. The study found that CARs is statistically significant for all of the three-event windows. In the two-day window, it is found that abnormal return increases by 15 BPS within these two days, which is almost $19.315 \%$ on an annual basis. It is also evident in the study that the effect of the announcement is more on small size firms.
\end{abstract}

Keywords: announcement date, Cumulative abnormal returns (CARs), events date, information asymmetry

\section{Introduction}

Lender identity, whether it is public or private; bank or non-bank, significantly affects the borrower's abnormal equity return. As information contains in the form of financing, so it influences the investors in the capital market. Investors in the market believe that banks work closely with the firm. That is why they should know more about the prospect of the firm's future as they are financing the firm's new venture or in the existing line, so they are supposed to see some financially viable future. According to Lummer and McConnell (1989), banks make lending decisions based on the insider information of borrowing firms and when the lending decisions become publicly available, it provides signals about borrowers' creditworthiness; and this is similar to the findings of James (1987); Mikkelson and Partch (1986); Marshall et al. (2019); and Chen et al. (2020).

Investors in the market believe that the bank got asymmetric information access about a firm. As banks invest in collecting information, it is a relative advantage in evaluating lending options. Benston and Smith (1976), Diamond (1984), and Campbell, Tim, and Kracaw (1980) has developed this idea in detail that a firm will get into a new loan agreement only if currently it has no bank financing or the terms of the new loan is more favourable than the existing one. These are the causes of why an investor in the capital market responds positively. Another way a bank can collect insider information about their customers over time is through an intimate continuing business relationship. Fama (1895) argue that banks play a unique role in providing loan to businesses. Bank debt is one type of inside debt, and banks got access to information not available to the holder of publicly traded securities or outside claims. On the other hand, bank loans get low priority among fixed-payoff claims, the credit renewal process is sound, and due to this reason, the monitoring costs incurred by the firm's other claimant's decreases. According to Fama's claim, bank loans place considerable weight on the bank loan process to transmit the information.

Different articles found that the market's reaction to the loan announcement differs from the borrower's characteristics. Slovin, Myron, Johnson, and Glascock (1992) found that larger firm receives a smaller amount of return on loan announcement, which is consistent with the Fama's (1985) suggestion that larger firms already operate under the scrutiny of numerous external monitors. Billett, Flannery, and Garfinkel (1995) found that borrower's return associated with non-bank loans is positive but not statistically different from the bank. Still, the creditworthiness of the lender does significantly influences the return of the borrower. 


\section{Literature Review}

Over the years, this research area attracted the attention of both researchers and practitioners. That is why there are a plethora of research works on this topic. Some of the very relevant works are reviewed to get a clear idea about the research question.

As an early bird, King (1966) stated that information influences the stock price reactions. He did not mention anything specific about the types of information but universally look at them. He found that the stock price reactions to new information differ from industry to industry in the long-run.

Fama (1985) has stated that banks play a unique role among all financing units. He claimed that bank loans serve as a strong signal of profitability and continuity of a firm. Earlier, Black (1975), and Kane and Malkiel (1965) have argued that banks got information advantage over other market participants because they can privately observe their depositors' payment behaviour.

Mikkelson and Partch (1986) have found and proved that bank's announcement of an extension of line credit upshot an increase in stock price. They conducted a longitudinal study of 360 firms, analyzed the market reaction around the announcement dates of different forms of financing, and found a positive relationship between bank loan agreement announcement and abnormal return on equity.

Researchers like Leland and Pyle (1977) and Ramakrishnan and Thakor (1984) have argued that financial intermediaries come into the play due to the information asymmetry in the market. In this intermediation process, banks are specialized in information generation. Benston and Smith (1976), and Diamond (1984), in the capital market, a borrowing firm's creditworthiness increases if a bank accepts a loan application of any borrower. Besides this, a bank also obtains client-specific information over time due to a close long-term relationship (Diamond, 1991).

Later on, James (1987) has confirmed all previous findings; in his study, James found that bank loan announcements positively affect the equity's return in the market. He amplified the existing literature that compares to the high stock price response of the straight public and private placement bank credit announcement.

After the seminal work of James (1987), Lummer and McConnel (1989) amplified the literature with distinct features of bank loan renewals and initiations. They found a positive relationship between bank loan renewal and stock price reaction in the market. This difference in the stock price reaction supports the bank has information asymmetry about the firm because of their ongoing monitoring activities for renewal decisions.

Slovin et al. (1992) have further investigated Lummer and McConnel's (1989) findings by adding different firm sizes in their study. They found little evidence between bank loan announcement and stock price reaction for a large firm but a significant relationship for small firms.

Billett et al. (1995) found significant evidence that lender quality shows a significantly different higher abnormal return. The creditworthiness of lenders significantly influences the market price of borrower's shares. Borrowing from a high-quality bank convey strong positive information about the borrower's growth. Their study also suggests that loans from a foreign bank convey more vital information about firm financial health because investors believe that foreign banks are more selective toward their borrower selection. Though their study is widely criticized for sample size, their main findings were reconfirmed by Byers et al. (1998).

Andre et al. (2001) studied the Canadian capital market with an additional dimension of how the market reacts to bank loan announcements after introducing Canadian authorities' capital adequacy requirements. Due to this requirement, a bank's monitoring commitment for the issuance of credit lines has decreased. The 1988's capital adequacy requirements of banks significantly differentiate the effect of bank loan announcements on small firms. Compare to the before 1988's, the cumulative abnormal returns for small firms was lower. So their findings support the statement that the government's rules significantly affect the announcement effects on the stock price.

Fery et al. (2003) conducted a study on the Australian capital market. They found a significant positive reaction in stock price movement in the market and bank loan announcements published in the financial press.

Ongena et al. (2014) found that bond prices strongly react to the bank loan announcement, and they also found that the effect of the form of loan announcement is -5 BPS for riskier and small firms, whereas it is 18 BPS for large and safer firms. On the other hand, Maskara and Mullinieux (2011) explore whether loan announcement is private or the public debt has no significant influence on the abnormal return.

Fields et al. (2006) found that after the seminal work of James (1987) and Lummer and McConnell (1989), the 
overall effect of the announcement of a bank loan agreement on borrower's equity securities has dropped significantly. According to them, after the ' 80 s, the relationship between a bank loan and market reaction has disappeared due to the changes in the financial system and abundance of information. These developments in the financial system minimized the information gap between firms and investors, decreasing the banks' monitoring and selection as sources of value to the investors.

$\mathrm{Li}$ and Ongena (2015) have also found that the abnormal return is large for less profitable firms. Their findings were surprisingly different from others; that is, information symmetry positively affect profitability. In this case, profitability behaves as a quality of information indicator for a firm.

From the past literatures, it is found that changes in economic conditions can influence the effect of bank loan announcements. Bailey et al. (2011) have investigated the chaises economy as a transitional economy. The state-owned banks in china issue loans based on the noisy liquidity condition of their borrowers. They found that a loan contract with a low-performing government bank negatively affects the borrowing firm's share price in the capital market.

Karim, Lih, and Karim (2012) have re-examined the relationship between bank loans and stock prices in Malaysia by using Granger Non-causality tests by bivariate and multivariate models with monthly and quarterly data. They found a contra to the existing relationship between stock price and bank loans, which means that stock prices and bank loans are independent.

Almutair (2015) investigated the dynamics of the relationship between bank loans and stock prices in Saudi Arabia applying quarterly data for 1998 to 2013. The study found a positive relationship between Saudi's stock market index (SSPI) and bank loans where the total bank loans (TOTALL) response positively to the increase in stock prices but not in other way arround. The author finally confirmed that TOTALL doesn't contribute any important role in transmitting stock market shocks to the real sector.

Chen, Ho, and Liu (2020) have used over 10000 loan announcement. They found that bank loan announcements strongly affect the borrowing firm's equity price. Firms with relatively lower abnormal spreads to the KMV-Merton default risk model have higher announcement return. They also found that bank loan announcement shows strong effect on stock price in earlier sample than the later sample.

Marshall et al. (2019) examined the stock market response to announcements of public bank and privately placed debt issuance by large UK firms surounding the global financial crisis of 2008. They found a positive reaction in stock prices to the announcements of bank debt issuance in the pre-crisis period. The authors also found decreasing abnormal returns on the announcement of bank loans from the financial crisis both in absolute term and in comparison to other borrowing sources. Finally, they concluded that bank loans have become less informative as a signal of the creditworthiness of borrowing firms in the period of financial crisis.

\subsection{Theoretical Development of Hypothesis and Research Question}

According to Billett et al. (1995), a lender's identity may convey information to an outside investor at least in two ways. First, the lender has known criteria for selecting borrowers according to the particular risk class. As the lenders collect private information in loan underwriting, the lending decision might convey valuable information about the borrower's actual risk. Second, according to Fama (1985), lenders have different monitoring abilities, enhancing the borrower's value by assuring that the borrower's proper investment and expenses decisions are taken.

A bank operates under more stringy supervision of the government than other non-bank lenders' do. So this might influence the choice of loan customers. Flannery (1989) found that due to government capital constraints, banks choose less risky individual loans. So from this information, an investor could make a favourable inference about the borrower's futures performance, as the loan was financed from a (constrained) commercial bank installed for a less constrained non-bank lender. There are three-way how the credit quality might also convey information to the borrower's equity holders. First, shared benefits from long-term customer relationships exist so that lender credit quality might influence the borrower's return. Second, as a bank underwrite and monitor consistently, so it generates economics of scale. Chemmanur and Ful-Ghieri (1994a) proposed a model in which banks are identified as specialized evaluators of a firm's actual value. They termed banks with better evaluative abilities are more reputed. Finally, they identified a loan renewal from a reputed bank, covey more supportive information than a less reputed one.

From all the literature mentioned earlier, it can be inferred that the effectiveness of bank loan announcement and market reaction is due to the information asymmetry in the capital market. This asymmetry means that in the capital markets, one party has superior information than others. Financial intermediation theory explains how 
bank alleviates these information asymmetries. According to Black (1975), Kane and Malkiel (1965), banks have more information than outsiders due to insider knowledge, and specific information arises from intimate partner relationships. Summing up all these theoretical arguments, the following hypothesis could be constructed.

$\mathrm{H}_{0}=$ announcement of bank loan agreement increases the abnormal return.

\section{Methodology}

\subsection{Sample Selection}

To find how the announcement of a bank loan could affect the stock returns. The study relays on some sources of information- (1) announcement date of the bank loan agreement; (2) the abnormal return of borrowing firm around the bank loan announcement; (3) firms quarterly fundamental.

\subsection{Bank Loan Characteristics and Event Dates}

From the Dealsacn, all the necessary bank loan announcement data about the USA market has been collected for the study. The entire database consists of 24010 loan issues data from 1995 to 2015.

\subsection{Borrower Characteristics}

As a control variable, we have selected borrower's total asset value to capture the firms' size, financial leverage, and total turnover to capture firms' growth rate. All these firm's characteristics have been collected from Compustat (by WRDS).

\subsection{Announcement Dates}

The loan agreement announcement date is the event date that is day ' 0 '. So, $[-1,0]$ will be considered as the main event window. To get a more in-depth insight into the effect of the announcement on stock return. The study has considered two more windows like the previous studies by different authors, i.e., three-day [-1, 1]; and five-day $[-2,2]$ window. As in the long run, some other events like managerial practices and industrial and public policy issues might affect its stock price.

\subsection{Returns}

The study has used Eventus (From WRDS), a daily introductory event study. In order to run the event studies, the study combined the CUSIP and announcement date in a unique identification string. Then it has been computed the daily stock returns.

$$
R_{i t}=\left(\left(P_{i t}-P_{i(t-1)}\right) / P_{i(t-1)} * 100+D i v_{i t}\right)
$$

$\mathrm{R}_{\mathrm{it}}$ stands for the firm's stock return on day $\mathrm{t}$ in percentages by considering possible dividend at time $t, \mathrm{P}_{\mathrm{it}}-\mathrm{P}_{\mathrm{i}(\mathrm{t}-1)}$ is the changes in price between time $t$ and ( $t-1)$. According to Ongena (2008), the study used 180 days before the event and 10 days after the event date as a pre-estimation period. This paper has considered the abnormal return for three different time windows: $[-1,0],[-1,1]$, and $[-2,2]$; here $[-1,0]$ is a two days event window, for one day before the event dates and the event day.

\subsection{Abnormal Returns}

This study is intended to reinvestigate the effect of bank credit agreements on the market value of a common stock. Likewise, in previous studies, this study will measure the effect of bank loan announcement on stock return by abnormal return in the announcement time window. An abnormal return is the actual stock return product in the event window minus the expected return on the same event window. To calculate the abnormal return market model has been used. The same procedure was employed by Mikkelson and Partch (1986), James (1987), Lummer and McConnell (1989).

$$
\begin{gathered}
R_{j t}=\widehat{\alpha}_{j}+\hat{\beta}_{j} R_{m t}+e_{j t} \\
e_{j t}=R_{j t}-\left(\widehat{\alpha}_{j}+\hat{\beta}_{j} R_{m t}\right)
\end{gathered}
$$

$\mathrm{R}_{\mathrm{jt}}$ is the rate of return of security $\mathrm{j}$ over period t. $R_{m t}$ is the rate of return on the CRSP equal-weighted market index over period $\mathrm{t}$, and $\widehat{\alpha}_{j}$ and $\widehat{\beta}_{j}$ are ordinary least squares estimates of firm j's market model parameters, and $e_{i t}$ is the random error terms.

\subsection{Cumulative Abnormal Returns (CARs)}

Now, by using the market returns on the stock, a cumulative abnormal return can be estimated for each event window:

$$
C A R_{j}=A R_{j t 1}+A R_{j t 2}=\sum_{t=t 1}^{t 2} A R_{j t}
$$

Where $C A R_{j}$ stands for cumulative abnormal return in the two days event window period, 
From this CARs we have calculated the CAAR - Cumulative average abnormal rate of returns over the cross-section of events.

\subsection{Univariate Analysis}

$$
C A A R=\frac{1}{N} \sum_{i=1}^{N} C A R_{j}
$$

Now, all CARs will be tested for each event window for the entire study period. To examine whether the following equation holds merit:

$$
C A R_{j}=0
$$

Now t-test will be employed to test the equation's significance if the equation is found statistically significant. Then it could be concluded that the bank loan announcements affect market returns.

\subsection{Multivariate Analysis}

In order to check the robustness of the prediction of explained variables, the study will run a multivariate regression. All the CARs have been regressed several other independent variables for 1995 to 2015.

$$
C A R_{j}=\propto+\sum_{j}^{N} \beta_{i} X_{j}+\varepsilon_{j}
$$

Here $C A R_{j}$ stands for the abnormal return of the event window being considered for company $\mathrm{j} . \propto$ represent the intercept, and $\sum_{j}^{N} B_{i} X_{j}$ represent the sum of all coefficients $\beta_{\mathrm{j}}$ of all independent variables. We have regressed seven independent variables in the equation, and the regression model (OLS) is as follows:

$$
\begin{gathered}
\text { CAR } R_{j}=\alpha+\beta_{1} \text { Frim size }+\beta_{2} \text { ROE }+\beta_{3} \text { Leverage }+\beta_{4} \frac{M}{B}+\beta_{5} \text { Tobin's } Q+\beta_{6} \text { Invt. grade } \\
+\beta_{7} N \text {. Ivst. grade }
\end{gathered}
$$

Where $\mathrm{CAR}_{\mathrm{j}}$ is the abnormal return for the event window for company $\mathrm{j}$. The $\beta_{1}, \beta_{2}, \beta_{3}, \beta_{4}$ and $\beta_{5}$ represent the company's general information. $\beta_{6}$ represent the company's investment grade, which is a dummy variable and $\beta_{7}$ represent the non-investment group is also a dummy variable. These two dummy variables are introduced to see how the quality of credit affects the abnormal return.

\section{Results and Discussion}

In this section, results are discussed and elaborated based on how a bank loan announcement affects the market price of a stock.

\subsection{Univariate Analysis}

The calculated statistics of cumulative abnormal returns(CARs) for the period of 1995 to 2015 has been presented in the table 1 . Here in the descriptive statistics table, mean, standard deviation, minimum, maximum, first quartile, and third quartile are represented. The table also reports two more statistics. (i) a two-tail t-statistic for testing CARs equals zero and (ii) the p-value of binomial test for a positive sign probability equaling 0.5 .

Table 1. Descriptive statistics and t-test results

\begin{tabular}{ccccccccc}
\hline Event Window & Mean & stDev (\%) & t-Test & Min $(\%)$ & p25 & Max (\%) & p75 & P-value \\
\hline$[-1 ; 0]$ & $0.15452 \%$ & $5.08624 \%$ & $4.7073^{* * *}$ & $-79.3587 \%$ & $-1.4994 \%$ & $362.7660 \%$ & $15.8845 \%$ & $0.000^{* * *}$ \\
{$[-1 ; 1]$} & $0.30467 \%$ & $6.24847 \%$ & $7.5553^{* * *}$ & $-88.8307 \%$ & $-1.8375 \%$ & $365.2664 \%$ & $2.0796 \%$ & $0.000^{* * *}$ \\
{$[-2 ; 2]$} & $0.48523 \%$ & $7.87658 \%$ & $9.5443^{* * *}$ & $-120.9928 \%$ & $-2.3995 \%$ & $366.8067 \%$ & $2.7939 \%$ & $0.000^{* * *}$ \\
\hline
\end{tabular}

$* * *, * *, *$ represent significant at $1 \%, 5 \%$, and $10 \%$ level.

Among all the event windows, the maximum change is in the five-day window, where the abnormal return increased by $366.8 \%$ and decreased by $120.99 \%$ with a variation of $7.877 \%$. In the case of the 3-days window highest increase is $365.25 \%$ and decreased to the lowest by $88.83 \%$. The study's research question is whether the announcement of bank loan agreements increases the stock price in the market. So to take a close look, the main window of this study is a 2-day window [-1;0]. Where shows that one day prior to the announcement date and on the announcement date, i.e. within this 2-days period, stock price increase by 15 basis point, which is statistically significant. If we convert it annually, then it becomes $19.315 \%$, so it is also economically significant. Compare to the average abnormal return found by Lummer and McConnell (1989) and Billett et al. (1995), it is low, as their finding was a significant abnormal return of 61 BPS and 61 BPS points, respectively. This reduction in coefficient is logical, according to Fields et al. (2006). After the James (1987) seminal work on the effect of firms' bank loan announcements on stock prices, the effect has almost disappeared due to the increasing efficiency of the financial system that reduces information asymmetry. However, this two-day CARs is close to Ongena et al. (2014), where they found an increase of 18 BPS. 
Table 2. Cumulative abnormal returns for big and small firms

\begin{tabular}{ccccc}
\hline Firm Size & Observation $(\mathrm{n})$ & CAARs & t-Test & p-value \\
\hline Firm Size<7.03609 & 11,603 & $0.1913 \%$ & $3.1584^{* * *}$ & $0.00160^{* * *}$ \\
Firm Size $>$ =7.03609 & 12,406 & $0.1201 \%$ & $4.1793^{* * *}$ & $0.000^{* * *}$ \\
\hline
\end{tabular}

$* * *, * * * *$ represent significant at $1 \%, 5 \%$, and $10 \%$ level.

In order to get a closer look, the studied firms are divided into two groups by the median of the firm size; here, the median of firm size is 7.03609. So more or equal to median firms are treated as large firms, and others are treated as small firms. For this purpose, only the main interested event (two-day) is considered. For both group mean of the cumulative abnormal are statistically significant. However, the effect of loan agreements on stock price is comparatively more on small firms. It is annually $23.9 \%$ for the small firm, whereas for the large firm, it is $15.01 \%$.

\subsection{Multivariate Analysis}

In the multivariate analysis, seven independent variables are regressed to estimate CARs. Among the seven, the 'investment grade and non-investment grade' are dummy variables. These two variables are included to check how the credit rating of the borrowing firm affect the abnormal return of a firm, and the other five are about the firm's specification. Column 1,2 , and 3 represent $[-1 ; 0],[-1 ; 1]$ and $[-2 ; 2]$ window respectively. The first independent variable, firm size, is negatively affecting CARs in all three times window though the effect is small, all are statistically significant, and the sign of the coefficient is consistent with the findings of the table 2 . That is, small size firms are more sensitive to CARs than large firms. The sign of the coefficient of return on equity positively affects the CARs in all event windows but is statistically significant for a two-day window only. That means profitability affect the CARs in a very short period. Tobin's $Q$ affects CARs significantly, but it takes time to adjust, for both three-day and five-day window is the sign indicating that its effect is native on abnormal return. Most surprisingly, the leverage is not significant in a two-day window, but for a three-day and five-day window, it is significant. May be this could be explained with the presumption that not all information is instantly reflected in the market price following the announcement, but it reflects after a certain time. However, it is significant for a five-day window to indicate that leverage increases the CARs, which is consistent with the results of $\mathrm{Li}$ and Ongena (2015), who claim that higher leverage generates more CARs. Both the dummy variables 'investment grade and non-investment grade' are not significant but the sign of the coefficient is meaningful, such as for all window non-investment grade negatively affect the CARs and for investment group other than three-day window rest of the two windows positively affect the CARs, which is theoretically consistent.

Table 3. Multivariate regression on whole sample

\begin{tabular}{|c|c|c|c|}
\hline Variables & (1) & (2) & (3) \\
\hline \multirow[t]{2}{*}{ Firm size (log assets) } & $-0.0005044^{* * *}$ & $-0.00063^{* * *}$ & $-0.0014^{* * *}$ \\
\hline & $(0.0002305)$ & $(0.000284)$ & $(0.0003567)$ \\
\hline \multirow[t]{2}{*}{ Return on equity } & $0.001773^{* * *}$ & 0.00064 & 0.00072 \\
\hline & $(0.0003601)$ & $(0.0004436)$ & $(0.000557)$ \\
\hline \multirow[t]{2}{*}{$\mathrm{M} / \mathrm{B}$} & $-0.000203^{* * *}$ & $-0.00015^{* * *}$ & $-0.0002^{* * *}$ \\
\hline & $(0.0000579)$ & $(0.0000714)$ & $(0.000089)$ \\
\hline \multirow[t]{2}{*}{ Tobin's Q } & 0.0002014 & $-0.0007^{* * *}$ & $-0.0015^{* * *}$ \\
\hline & $(0.0002186)$ & $(0.0002693)$ & $(0.0003383)$ \\
\hline \multirow[t]{2}{*}{ Leverage } & 0.0008487 & -0.00134 & $0.00525^{* * *}$ \\
\hline & $(0.0016259)$ & $(0.002005)$ & $(0.0025167)$ \\
\hline \multirow[t]{2}{*}{ Ivst. grade } & 0.0004344 & -0.00058 & .000033 \\
\hline & $(0.00116)$ & $(0.001429)$ & $(0.00179)$ \\
\hline \multirow[t]{2}{*}{ N.ivst.grade } & -0.0001384 & -0.00073 & -0.0026 \\
\hline & $(0.0009257)$ & $(0.00114)$ & $(0.00143)$ \\
\hline \multirow[t]{2}{*}{ Intercept } & $0.0049177^{* * *}$ & $0.009807^{* * *}$ & $0.01699^{* * *}$ \\
\hline & $(0.0014989)$ & $(0.001846)$ & $(0.00232)$ \\
\hline R-square & 0.0016 & 0.0011 & 0.0027 \\
\hline
\end{tabular}




\section{Conclusion}

From the univariate analysis, it could be concluded that the announcement of bank loan agreements significantly affects the generation of cumulative abnormal returns (CARs). So the hypothesis of the study is correct that the announcement of a bank loan agreement increases the CARs of the borrowing firm's equity in the market. The mean of CARs of the two-days window is $19.315 \%$ which is significant both statistically and economically. The effect of the announcement of the bank loan agreement is of different magnitude depending on the firm's size. The return of small size firm affected more than the large size frims'. The findings of this study are similar to the previous documentation like James (1987), and Mikkelson and Partch (1986) that positive excess returns are generated by the announcement of a bank loan agreement. So this also supports the argument that banks got the unique capacity to generate information, which reduces the information asymmetry of the market.

\section{Limitation and Further Research}

This study is based on the assumption that investors in the market will react to the information available. So the first limitation is that the market is believed to be efficient in semi-strong form. Investors have to believe that a bank agrees to extend a loan on the ground that unbiased audit reports about the borrowing firm's current conditions and prospects. The study also assumes that there is no other significant event within the event window either from the borrowing firm's side or from the market side as a whole. That means each event date is free from any other significant event. Another crucial shortcoming of the study is that no macroeconomic factor is considered to measure the market sensitivity of the investor. However, the efficiency of financial, public rules and regulations, central bank's policies significantly affect the operation of banking financial institutions. Here we have considered information asymmetry as one of the prime causes of generating abnormal returns. Sometimes the market reacts positively to an announcement of the renewal, but it was previously a troubled loan. Bank has restructured the loan to get additional security or higher interest rates. In both cases, the bank uses internal information, signalling an intent of the bank to work with the borrower. We think it will be worthy if macroeconomic variables are taken into consideration to calculate the abnormal returns and see how policy changes might affect the information asymmetry.

\section{References}

Almutair, S. (2015). Dynamics of the relationship between bank loans and stock prices in Saudi Arabia. International Business \& Economics Research Journal (IBER), 14(3), 439-452. https://doi.org/10.19030/iber.v14i3.9209

Andre, P., Mathieu, R., \& Zhang, P. (2001). A note on: Capital adequacy and the information content of term loans and lines of credit. Journal of Banking \& Finance, 25(2), 431-444. https://doi.org/10.1016/S0378-4266(99)00130-2

Bailey, W., Huang, W., \& Yang, Z. (2011). Bank Loans with Chinese Characteristics: Some Evidence on Inside Debt in a State-Controlled Banking System. Journal of Financial and Quantitative Analysis, 46(6), 1795-1830. https://doi.org/10.1017/S0022109011000433

Benston, G., \& Smith, C. (1976). A Transactions Cost Approach to the Theory of Financial Intermediation. The Journal of Finance, 31(2), 215-231. https://doi.org/10.2307/2326596

Billett, M., Flannery, M., \& Garfinkel, J. (1995). The Effect of Lender Identity on a Borrowing Firm's Equity Return. The Journal of Finance, 50(2), 699-718. https://doi.org/10.2307/2329425

Black, F. (1975). Bank funds management in an efficient market. Journal of Financial Economics, 2, 323-339. https://doi.org/10.1016/0304-405X(75)90008-2

Byers, S., Fraser, D., \& Shockley, R. (1998). Lender Identity and Borrower Returns: The Evidence from Foreign Bank Loans to U. S. Corporations. Global Finance Journal, 9, 81-94. https://doi.org/10.1016/S1044-0283(98)90016-3

Campbell, T., \& Kracaw, W. (1980). Information Production, Market Signalling, and the Theory of Financial Intermediation. The Journal of Finance, 35(4), 863-882. https://doi.org/10.2307/2327206

Chemmanur, T. J., \& Paolo, F. (1994a). Reputation, renegotiation, and the choice between bank loans and publicly traded debt. Review of Financial Studies, 7, 475-506. https://doi.org/10.1093/rfs/7.3.475

Chen, S., Ho, S. W., \& Liu, C. (2020). Bank Loan Announcement Effects-Evidence from a Comprehensive 8-K Sample. PBCSF-NIFR Research Paper. https://doi.org/10.2139/ssrn.3480906

Diamond, D. W. (1984). Financial intermediation and delegated monitoring. Review of Economic Studies, 51, 
393-414. https://doi.org/10.2307/2297430

Diamond, D. W. (1991). Monitoring and reputation: The choice between bank loans and directly placed debt. Journal of Political Economy, 99, 689-721. https://doi.org/10.1086/261775

Fama, E. F. (1985). What's different about banks?. Journal of Monetary Economics, 15(1), 29-39. https://doi.org/10.1016/0304-3932(85)90051-0

Fery, J., Gasbarro, D., Woodliff, D. R., \& Zumwalt, J. K. (2003). Market reaction to published and non-published corporate loan announcements. The Quarterly Review of Economics and Finance, 43(1), 1-10. https://doi.org/10.1016/S1062-9769(02)00118-7

Flannery, M. J. (1989). Capital regulation and insured banks choice of individual loan default risks. Journal of Monetary Economics, 24(2), 235-258. https://doi.org/10.1016/0304-3932(89)90005-6

James, C. (1987). Some evidence on the uniqueness of bank loans. Journal of Financial Economics, 19(2), 217-235. https://doi.org/10.1016/0304-405X(87)90003-1

Kane, E. J., \& Malkiel, B. G. (1965). Bank portfolio allocation, deposit variability, and the availability doctrine. The Quarterly Journal of Economics, 113-134. https://doi.org/10.2307/1880516

Karim, B. A., Lih, L. S., \& Karim, Z. A. (2012). Bank loans and stock prices: An empirical evidence. Aceh International Journal of Social Science, 1(2). https://doi.org/10.12345/aijss.1.2.1526

King, B. F. (1966). Market and industry factors in stock price behavior. The Journal of Business, 39(1), 139-190. https://doi.org/10.1086/294847

Leland, H. E., \& Pyle, D. H. (1977). Informational asymmetries, financial structure, and financial intermediation. The Journal of Finance, 32(2), 371-387. https://doi.org/10.2307/2326770

Li, C., \& Ongena, S. (2015). Bank loan announcements and borrower stock returns before and during the recent financial crisis. Journal of Financial Stability, 21, 1-12. https://doi.org/10.1016/j.jfs.2015.09.006.

Lummer, S. L., \& McConnell, J. J. (1989). Further evidence on the bank lending process and the capital-market response to bank loan agreements. Journal of Financial Economics, 25(1), 99-122. https://doi.org/10.1016/0304-405X(89)90098-6

Marshall, A., McCann, L., \& McColgan, P. (2019). The market reaction to debt announcements: UK evidence surrounding the global financial crisis. The British Accounting Review, 51(1), 92-109. https://doi.org/10.1016/j.bar.2018.04.001

Maskara, P. K., \& Mullineaux, D. J. (2011). Information asymmetry and self-selection bias in bank loan announcement studies. Journal of Financial Economics, 101(3), 684-694. https://doi.org/10.1016/j.jfineco.2011.03.019

Mikkelson, W. H., \& Partch, M. M. (1986). Valuation effects of security offerings and the issuance process. Journal of Financial Economics, 15(1-2), 31-60. https://doi.org/10.1016/0304-405X(86)90049-8

Ongena, S., Roşcovan, V., Song, W. L., \& Werker, B. J. (2014). Banks and bonds: The impact of bank loan announcements on bond and equity prices. Journal of Financial Management, Markets and Institutions, 2(2), 131-156. https://doi.org/10.12831/78756

Ramakrishnan, R. T., \& Thakor, A. V. (1984). Information reliability and a theory of financial intermediation. The Review of Economic Studies, 51(3), 415-432. https://doi.org/10.2307/2297431

Slovin, M. B., Johnson, S. A., \& Glascock, J. L. (1992). Firm size and the information content of bank loan

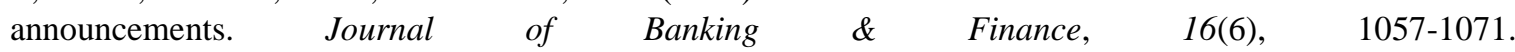
https://doi.org/10.1016/0378-4266(92)90059-9

\section{Copyrights}

Copyright for this article is retained by the author(s), with first publication rights granted to the journal.

This is an open-access article distributed under the terms and conditions of the Creative Commons Attribution license (http://creativecommons.org/licenses/by/4.0/). 